DOI: $10.2478 / \mathrm{v} 10014-011-0002-\mathrm{z}$

Agrovoc descriptors: solanum,drug plants,plant propagation,in vitro experimentation,organogenesis,stems, growing media,explants,internodes

Agris category code: F02

\title{
Mass propagation of Solanum surattense Bum. using direct adventitious shoot organogenesis from internode
}

\author{
Md. Mahabubur RAHMAN ${ }^{1,2^{*}}$, Muhammad Nurul AMIN $^{2}$, Md. Zohurul ISLAM ${ }^{2}$, Rubaiyat Sharmin SULTANA ${ }^{2}$
}

Received November 6, 2010; accepted February 18, 2011. Delo je prispelo 03. junija 2004, sprejeto 15. oktobra 2004.

\begin{abstract}
An efficient and reproducible procedure was established for direct shoot regeneration of Solanum surattense Bum. using internodal explants. The shoot regeneration efficiency on Murashige and Skoog (MS) medium supplemented with 6benzylaminopurine (BAP) was superior in compared to 6furfurylaminopurine $(\mathrm{Kn})$. The highest mean number of shoots per explant was recorded on MS medium containing $0.5 \mathrm{mgl}^{-1}$ BAP. BAP alone was more effective for shoot regeneration than combination of BAP and $\alpha$-naphthaleneacetic acid (NAA). The number of shoot per explant was highest in the $4^{\text {th }}$ subculture and then it was remained stable up to $6^{\text {th }}$ subculture. The shoot number drastically reduced from $7^{\text {th }}$ subculture when explants were repeated subculturing up to $8^{\text {th }}$ subculture. Hundred percent adventitious shoots were rooted successively on half strength MS medium fortified with 0.05 $\mathrm{mgl}^{-1}$ NAA. At about $90 \%$ of the in vitro-propagated plantlets survived when they were transferred to ex vitro conditions for acclimatization.
\end{abstract}

Key words: Direct shoot organogenesis, internodal explant, in vitro, medicinal plant, Solanum surattense

\section{IZVLEČEK}

\section{RAZMNOŽEVANJE Solanum surattense Bum. Z UPORABO INTERNODIJSKIH EKSPLANTOV}

Avtorji so razvili učinkovit in reproducibilen način neposredne organogeneze zdravilne rastline Solanum surattense Bum. $\mathrm{z}$ uporabo internodijskih eksplantov. Regeneracija na gojišču Murashige in Skoog (MS) je bila bolj uspešna $\mathrm{z}$ dodatkom 6benzilaminopurina (BAP) $\mathrm{v}$ primerjavi $\mathrm{z}$ uporabo 6furfurilaminopurina $(\mathrm{Kn})$. Največje število poganjkov na eksplant je bilo na gojišču MS z 0,5 mg/l BAP. BAP sam je bil bolj učinkovit za regeneriranje poganjkov kot kombinacija BAP in $\alpha$-nafthalenocetne kisline (NAA). Število poganjkov na eksplant je bilo najvišje $\mathrm{v}$ četrti subkulturi in je ostalo stabilno vse do šeste, močno pa se je zmanjšalo $\mathrm{v}$ sedmi in osmi subkulturi. Adventivne korenine so se pojavile pri vseh poganjkih pri MS mediju polovične jakosti z dodatkom 0,05 $\mathrm{mg} / \mathrm{l}$ NAA. Približno $90 \%$ in vitro razmnoženih rastlinic je preživelo prenos ex vitro in aklimatizacijo.

Ključne besede: neposredna organogeneza poganjkov, eksplanti internodijev, in vitro, zdravilna rastlina, Solanum surattense

\section{INTRODUCTION}

Solanum surattense Bum. (Solanaceae) is a perennial herb. It is usually found in India, Pakistan, Malaya, and Australia. In Bangladesh, it was found as wild herb in almost all northern parts and it was very common in the Barind region. Nowadays, this plant rarely gets in the Barind region only. The solasodine and glycosides are rich in this plant, are very common properties for anticancer (Cham, 2007). Besides, this plant is widely used as folk medicine for breathing trouble, heart diseases and pain. Some drug companies (Unani, Hamdard Laboratories, Ayurvedic) are developed in Bangladesh based on plant extract and they are attracted by the people. These companies are using extract of $S$. surattense as to prepare remedy for breathing disease, as well this plant is widely planted in highland of Bangladesh. Since this herb becoming a potential medicinal plant in south Asia, more advance investigations are needed concerning modification of

\footnotetext{
${ }^{1}$ Present address: Research Institute of Sustainable Humanosphere, Kyoto University, Uji, Kyoto 611-0011, Japan, *Fax: +81-774-38-3682, *Email: mahabubur@ rish.kyoto-u.ac.jp

2 Department of Botany, University of Rajshahi, Rajshahi 6205, Bangladesh
} 
characteristics including rapid growth, increase essential chemicals content, disease resistant and stress tolerance in this plant.

Limited reports have been published on the in vitro propagation as well as genetic transformation systems of S. surattense. Pawar et al. (2002) developed a technique for direct shoot organogenesis from shoot tip and leaf segments. Using nodal and shoot tip segments, a micropropagation technique also established on this plant by Rama Swamy et al. (2004). Rama Swamy et al. (2005a) established a protocol on plantlet regeneration through somatic embryogenesis from cotyledon and leaf explants. Callus induction and shoot organogenesis system from floral bud were also reported earlier for this plant proliferation (Prasad et al., 1998). Rama Swamy (2006) reported Agrobacterium-mediated genetic transformation systems using leaf explants of $S$. surattense. (Rama Swamy et al. 2005b) established streptomycin-resistant $S$. surattense plantlets using in vitro mutagenesis.
For genetic improvement of plant, we usually use selection method as well as in vitro molecular breeding technique. Plant breeders showing great interest on molecular breeding technique for plant modification genetically because conventional selection method takes long time, tedious and occurs large variation within clones. For molecular breeding based genetic transformation, we know, efficient regeneration systems are prime requirement. Stem segments are used as important explant for genetic transformation system, described in many plant species (e.g., Rastogi and Dwivedi, 2006). Adventitious shoot regeneration from internodal segments of $S$. surattense was not published in the previous reports so far.

In the present study an effort was made to establish a protocol for the in vitro propagation of $S$. surattense from the internodal explants of field grown plant through direct adventitious shoot organogenesis.

\section{MATERIALS AND METHODS}

\section{Explant preparation}

Shoot apices $(20-25 \mathrm{~cm})$ with leaves of $S$. surattense were collected from field growing plant in a Barind region, Rajshahi, Bangladesh. The shoot apices were defoliated and segmented at $4-5 \mathrm{~cm}$ contains 2-3 nodes after bringing to laboratory. Stem segments were washed thoroughly under running tap water for $30 \mathrm{~min}$ and finally disinfected with $0.1 \%$ $\mathrm{HgCl}_{2}$ for 10 min under laminar airflow followed by washing thrice with autoclaved distilled water. The internodal segments $(1 \mathrm{~cm})$ were prepared from the disinfected plant materials.

\section{Culture media and conditions}

Three basal media were used in the present study: Murashige and Skoog (MS) medium, Gamborg (B5) medium and McCown Woody Plant medium (WPM). All variants of medium were supplemented with $3 \%$ (w/v) sucrose. The $\mathrm{pH}$ of medium was adjusted to $5.7 \pm 0.2$ before autoclaving at $121^{\circ} \mathrm{C}$ for 20 min under $1.1 \mathrm{kgcm}^{-2}$ pressure and medium was solidified with $0.8 \%$ (w/v) agar (Type M, Sigma). The MS medium was variously supplemented with 6benzylaminopurine (BAP) at $0.2,0.5$ and $1 \mathrm{mgl}^{-1}, 6$ Furfurylaminopurine $(\mathrm{Kn})$ at $0.5,1$ and $1.5 \mathrm{mgl}^{-1}$ alone or in combinations with $\alpha$-Naphthaleneacetic acid (NAA) at 0.1 and $0.2 \mathrm{mgl}^{-1}$ for shoot regeneration. Half strength MS medium supplemented with various concentrations of NAA, Indole-3butyric acid (IBA) or Indole-3-acetic acid (IAA) singly was used for rooting. Plant growth regulator (PGR)-free medium was considered as control for both shoot regeneration and rooting experiments. All cultures were maintained in the growth chamber under $25 \pm 1^{\circ} \mathrm{C}$ with $16 \mathrm{~h}$ photoperiod (50 $\mu \mathrm{mol} \mathrm{m} \mathrm{m}^{-2}$ ) provided by cool white fluorescent light.

\section{Culture and acclimatization procedures and data collection}

After disinfection, internodal explants were cultured on the MS medium fortified with PGRs for shoot multiplication. Cultures were transferred to fresh medium routinely at 15-dayinterval. Elongated shoots (at least $3 \mathrm{~cm}$ ) were excised from shoot clusters prior to subculture. Large-sized shoot clusters were divided before transfer to fresh medium. Data were collected on percentages of explant forming shoot, total number and average length of shoots per explant 30 days after culture. Using $0.5 \mathrm{mgl}^{-1}$ BAP as standard PGR, shoot regeneration ability was evaluated among three basal media.

The effect of repeated subculturing on shoot regeneration efficiency was evaluated by another experiment. Ten internodal segments were passed (15-day-interval) continuously up to 8 subcultures on shoot-regenerating medium. Elongated shoots (at least $3 \mathrm{~cm}$ long) were excised from shoot clumps prior to transfer onto fresh medium. Data on total number and average length of elongated shoots per explant were recorded in each subculture (15-day-interval).

For rooting, leafy shoots ( $3 \mathrm{~cm}$ to above) were implanted onto half strength MS basal medium containing auxins and one shoot was cultured in one test tube. Data were collected on percentages of shoot forming root, total number and average length of roots per plantlet 21 days after culture.

For acclimatization of plantlets, rooted shoots were washed gently under running tap water, planted onto pot containing composed soil and maintained in the room conditions for 7 days. Plantlets were covered with polyethylene bag for avoiding over transpiration and watered regularly 2-dayinterval. Seven days after hardening in room conditions, plantlets were transferred to out side conditions and survival rate was recorded 2 months after transfer. 


\section{Statistical analysis}

All experiments were consisted of five replicates and repeated at least thrice. For shoot regeneration experiment, 6 internodal segments were used for each replicates, which were collected from one field grown plant. Five in vitro shoots were taken in a replication for rooting experiment, which were regenerated from one explant taken from one field grown plant. Therefore, variation within replications indicates difference within genotypes. Data were arranged as a completely randomized design and significant difference was determined by analysis of variance. Differences among mean values were evaluated by least significance difference (LSD) at the 5\% ( $p \leq 0.05)$ level.

\section{RESULTS AND DISCUSSION}

\section{Direct adventitious shoot organogenesis}

The stem segments of field growing plant were very prickly, in which disinfection was problematic; however, surface-disinfection with $0.1 \% \mathrm{HgCl}_{2}$ solution for $10 \mathrm{~min}$ resulted in the highest contamination free of about $45 \%$ explants. The frequencies of shoot regeneration varied from 20 to $100 \%$ depending on the PGRs (Table 1). On MS medium supplemented with BAP $(0.5 \mathrm{mgl}-1)$, the adventitious shoot induction at the cut side was first observed 7 days after inoculation without any callus intervention. Within 15 days, shoot induction obtained from not only from cut sides but also from the intact portion of internode, while some of first induced shoots were reached a height of above $3 \mathrm{~cm}$ (Fig. 1a). After separation of elongated shoots, shoot clusters were divided prior to subculture onto fresh same variant of medium, resulted in the highest production of adventitious shoots, on which $100 \%$ internodal segments produced 58.2 shoots per explant within 30 days after subculture (Fig. 1b). No regeneration of any shoot was observed on PGR-free medium. The differences in the shoot regeneration efficiency were significant $(p \leq 0.05)$ among the PGRs supplemented (Table 1). Within replications, the significant differences were not observed, in which differences in the shoot regeneration efficiency did not exhibit within genotypes. The shoot regeneration performances were low in MS medium supplemented with $\mathrm{Kn}$ in compared to medium containing BAP. The superior effect of BAP in compared to Kn was reported on direct adventitious shoot regeneration from leaf explant of Santalum album (Mujib, 2005). In contrast to present observations, medium containing BAP or Kn showed similar responses on in vitro shoot production of Solanum nigrum (Bhat et al., 2010). In previous report on adventitious shoots regeneration of $S$. surattense (Pawar et al., 2002), adventitious shoots were produced from shoot tip and leaf explants on MS basal medium fortified with BAP and kinetin individually and in their combination.

Table 1: The adventitious shoots proliferation from the internodal explants of $S$. surattense on MS medium fortified with PGRs 30 days after culture.

\begin{tabular}{|c|c|c|c|c|c|}
\hline \multicolumn{3}{|c|}{ PGRs $\left(\mathrm{mgl}^{-1}\right)$} & \multirow{2}{*}{$\begin{array}{l}\text { Percentages of explant } \\
\text { forming adventitious } \\
\text { shoot (Mean } \pm \text { SE) }\end{array}$} & \multirow{2}{*}{$\begin{array}{l}\text { Number of total } \\
\text { shoots per explant } \\
(\text { Mean } \pm \text { SE) }\end{array}$} & \multirow{2}{*}{$\begin{array}{l}\text { Average length }(\mathrm{cm}) \\
\text { of shoots per explant } \\
(\text { Mean } \pm \mathrm{SE})\end{array}$} \\
\hline BAP & $\mathrm{Kn}$ & NAA & & & \\
\hline 0 & 0 & 0 & 0 & 0 & 0 \\
\hline 0.2 & & & $43.3 \pm 2.8 f$ & $12.4 \pm 1.2 \mathrm{~d}$ & $4.0 \pm 0.3 c$ \\
\hline 0.5 & & & $100 \pm 0.0 \mathrm{a}$ & $58.2 \pm 4.6 \mathrm{a}$ & $6.7 \pm 0.4 a$ \\
\hline 1.0 & & & $90 \pm 12.1 b$ & $25.5 \pm 2.4 b$ & $5.5 \pm 0.3 b$ \\
\hline 2.0 & & & $30 \pm 2.8 \mathrm{~g}$ & $7.5 \pm 0.8 \mathrm{~d}$ & $3.4 \pm 0.2 \mathrm{~d}$ \\
\hline & 0.5 & & $26.7 \pm 3.5 \mathrm{~g}$ & $4.5 \pm 0.5 \mathrm{de}$ & $3.5 \pm 0.4 \mathrm{~cd}$ \\
\hline & 1.0 & & $66.7 \pm 5.4 \mathrm{~d}$ & $16.7 \pm 1.3 \mathrm{c}$ & $5.2 \pm 0.2 b$ \\
\hline & 1.5 & & $80 \pm 6.5 \mathrm{c}$ & $30.6 \pm 3.1 b$ & $6.5 \pm 0.3 \mathrm{a}$ \\
\hline & 3.0 & & $30 \pm 2.8 \mathrm{~g}$ & $5.7 \pm 0.4 \mathrm{~d}$ & $3.1 \pm 0.4 \mathrm{~d}$ \\
\hline 0.5 & & 0.1 & $56.7 \pm 4.5 \mathrm{e}$ & $22.6 \pm 3.5 b c$ & $4.8 \pm 0.4 b c$ \\
\hline 0.5 & & 0.2 & $43.3 \pm 2.6 f$ & $13.5 \pm 3.8 \mathrm{~cd}$ & $4.0 \pm 0.3 c$ \\
\hline 1.0 & & 0.1 & $30 \pm 4.3 \mathrm{~g}$ & $6.2 \pm 0.6 \mathrm{~d}$ & $3.2 \pm 0.2 \mathrm{~d}$ \\
\hline 1.0 & & 0.2 & $23.3 \pm 2.8 \mathrm{~g}$ & $5.6 \pm 0.2 \mathrm{de}$ & $3.0 \pm 0.3 \mathrm{~d}$ \\
\hline & 1.0 & 0.1 & $23.3 \pm 2.4 \mathrm{~g}$ & $4.1 \pm 0.6 \mathrm{e}$ & $3.2 \pm 0.3 \mathrm{~d}$ \\
\hline & 1.0 & 0.2 & $20 \pm 3.2 \mathrm{gh}$ & $3.7 \pm 0.3 \mathrm{e}$ & $3.0 \pm 0.4 \mathrm{~d}$ \\
\hline & 1.5 & 0.1 & $40 \pm 3.4 \mathrm{f}$ & $12.4 \pm 1.0 \mathrm{~d}$ & $4.5 \pm 0.4 b c$ \\
\hline & 1.5 & 0.2 & $20 \pm 2.1 \mathrm{gh}$ & $5.2 \pm 0.5 \mathrm{~d}$ & $4.1 \pm 0.3 c$ \\
\hline
\end{tabular}

Means with the same letters are not significantly different by the LSD test at the 5\% level $(p \leq 0.05)$. 
Md. Mahabubur RAHMAN in sod.

Table 2: Ions in three basal media used for shoot organogenesis of $S$. surattense.

\begin{tabular}{lccc}
\hline \multicolumn{2}{l}{ Macro and microelement combinations $(\mathrm{mM})$} & & WPM \\
\hline Ions & $\mathrm{MS}$ & 9.700 & B5 \\
\hline $\mathrm{NO}_{3}{ }^{-}$ & 39.310 & 1.240 & 1.090 \\
$\mathrm{H}_{2} \mathrm{PO}_{4}^{-}$ & 1.250 & 7.300 & 2.086 \\
$\mathrm{SO}_{4}{ }^{-}$ & 1.620 & 1.300 & 2.040 \\
$\mathrm{Cl}^{-}$ & 5.980 & 12.615 & 24.735 \\
$\mathrm{~K}^{+}$ & 19.955 & 3.000 & 1.020 \\
$\mathrm{Ca}^{2+}$ & 2.999 & 0.102 & 1.190 \\
$\mathrm{Na}^{+}$ & 0.102 & 1.500 & 1.010 \\
$\mathrm{Mg}^{2+}$ & 1.500 & 5.000 & 2.020 \\
$\mathrm{NH}_{4}{ }^{+}$ & 20.610 & 14.700 & 26.750 \\
$\mathrm{Total} \mathrm{N}^{+}$ & 59.920 & $1: 0.515$ & $1: 0.082$ \\
$\mathrm{NH}_{4}^{+}: \mathrm{NO}_{3}{ }^{-}$ & $1: 0.524$ & & \\
\hline
\end{tabular}

Table 3: Root formation from the in vitro grown shoots of $S$. surattense on half strength MS medium fortified with auxins 21 days after culture.

\begin{tabular}{|c|c|c|c|c|c|}
\hline \multicolumn{3}{|c|}{ Auxins $\left(\mathrm{mgl}^{-1}\right)$} & \multirow{2}{*}{$\begin{array}{l}\text { Percentages of shoot } \\
\text { forming root } \\
(\text { Mean } \pm \text { SE })\end{array}$} & \multirow{2}{*}{$\begin{array}{c}\text { Number of roots per } \\
\text { plantlet } \\
(\text { Mean } \pm \text { SE })\end{array}$} & \multirow{2}{*}{$\begin{array}{c}\text { Length of roots per } \\
\text { plantlet } \\
(\text { Mean } \pm \text { SE) }\end{array}$} \\
\hline NAA & IBA & IAA & & & \\
\hline 0 & 0 & 0 & $65 \pm 4.2 \mathrm{c}$ & $2.7 \pm 0.3 \mathrm{de}$ & $2.5 \pm 0.2 b$ \\
\hline 0.01 & & & $100 \pm 0.0 \mathrm{a}$ & $9.2 \pm 0.8 b$ & $3.0 \pm 0.3 \mathrm{a}$ \\
\hline 0.05 & & & $100 \pm 0.0 \mathrm{a}$ & $12.5 \pm 1.2 \mathrm{a}$ & $3.2 \pm 0.4 \mathrm{a}$ \\
\hline 0.1 & & & $80 \pm 6.2 b$ & $5.8 \pm 0.3 \mathrm{c}$ & $2.8 \pm 0.3 \mathrm{ab}$ \\
\hline & 0.01 & & 0 & 0 & 0 \\
\hline & 0.05 & & $80 \pm 5.6 b$ & $3.6 \pm 0.3 \mathrm{~d}$ & $2.0 \pm 0.3 c$ \\
\hline & 0.1 & & 0 & 0 & 0 \\
\hline & & 0.01 & 0 & 0 & 0 \\
\hline & & 0.05 & $60 \pm 6.4 \mathrm{~cd}$ & $2.8 \pm 0.2 \mathrm{~d}$ & $1.4 \pm 0.2 \mathrm{~d}$ \\
\hline & & 0.1 & 0 & 0 & 0 \\
\hline
\end{tabular}

Means with the same letters are not significantly different by the LSD test at the 5\% level $(p \leq 0.05)$.

The MS medium supplemented with the combination of NAA and BAP or Kn significantly $(p \leq 0.05)$ reduced the shoot regeneration efficiencies. On medium supplemented with combinations of NAA and BAP, the abnormalities such as thick shoot and light green leaves were observed in the induced shoots, which were finally turned lethal browning at the $3^{\text {rd }}$ subculture (45 days after culture). The results are in agreement with the finding of Teo et al. (1997) on the shoots multiplication of Brassica rapa, they observed that regenerated shoot shows abnormalities after addition of high concentration NAA to the medium. The contrary result was observed in the direct shoot regeneration of Drymaria cordata form leaf segment (Ghimire et al., 2010) where they reported that the application of NAA and BAP in the medium was enhanced the shoot regeneration. In $S$. surattense, the combination of BAP and NAA resulted in the best somatic embryogenesis when cotyledon and leaf explant were used (Rama Swamy et al., 2005a). Although the presence of NAA in combination with cytokinins enhancing morphogenesis and somatic embryogenesis reported in earlier studies, this combination inhibited direct shoot regeneration of $S$. surattense in the present investigation but reasons for this fact are unknown.
As shown in the Table 2, the content of ions in three basal media was presented. Total nitrogen content was higher in MS medium than in WPM and B5 media although ratio of $\mathrm{NH}_{4}{ }^{+}$and $\mathrm{NO}_{3}{ }^{-}$was similar in MS and WPM media. Of three basal media tested, the percentage of explant forming shoot, number and length of shoot per explant were the highest in MS medium. The percentage and length of shoot were lower nearly twice in WPM and B5 than MS medium, while the number of regenerated shoot was about trice higher in MS than those of WPM and B5 media (Fig. 2). The lack of responses in the shoot regeneration efficiency may be occurred in WPM and B5 media due to nitrogen (N) deficiency. This trend is in agreement with the finding of Pinto et al. (2008). An appropriate $\mathrm{NO}_{3}{ }^{-}: \mathrm{NH}_{4}{ }^{+}$ratio influenced morphogenesis and embryogenesis (Ramage and Williams, 2002) but the most favorable range depends on the species (e.g., Tazawa and Reinert, 1969). Also different $\mathrm{NO}_{3}{ }^{-}: \mathrm{NH}_{4}{ }^{+}$levels may have indirect effects to $\mathrm{pH}$ changes, which control cation absorption and eventually morphogenesis (Cousson and Tran Thanh Van, 1993). Other ions such as $\mathrm{Ca}^{2+}, \mathrm{Mg}^{2+}$, $\mathrm{SO}_{4}{ }^{2-}, \mathrm{H}_{2} \mathrm{PO}_{4}^{-}, \mathrm{Cl}^{-}$, and $\mathrm{K}^{+}$were also correlated with morphogenesis (Benson, 2000; Pinto et al., 2008). In the present study, shoot regeneration of $S$. surattense was 
influenced on MS medium, may be reasons were high content of nitrogenous elements and even appropriate proportion of $\mathrm{NO}_{3}{ }^{-}$and $\mathrm{NH}_{4}{ }^{+}$. Using $\mathrm{MS}$ medium, in vitro propagation of $S$. surattense was inspected by all previous reporters although they not did compare with other basal media. In the present study, we examined comparative study on three basal media and observed that MS medium was superior effective on in vitro shoot regeneration.
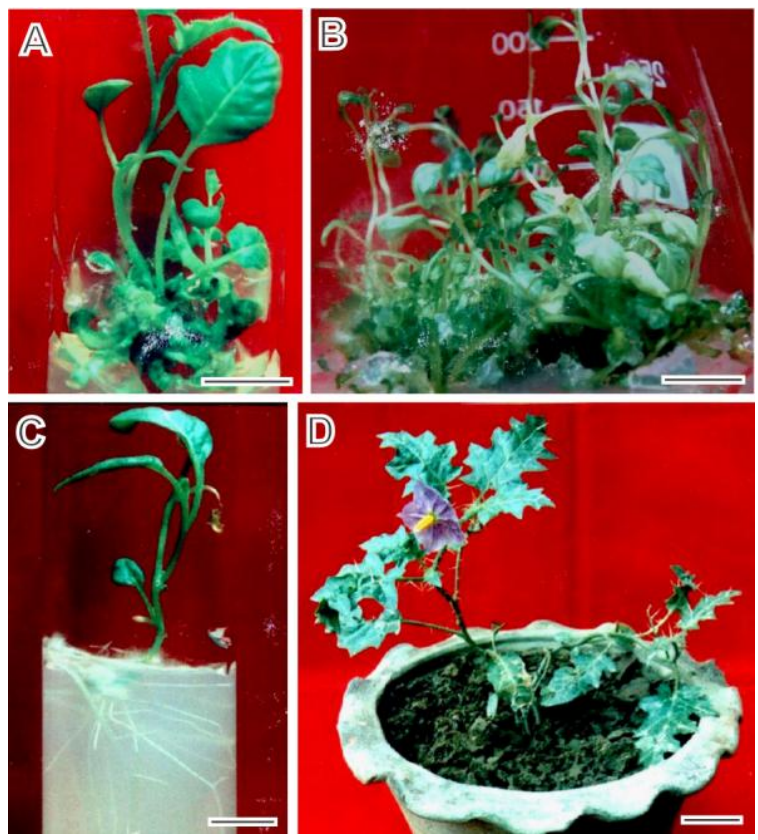

Fig. 1. In vitro multiplication of Solanum surattense through direct shoot organogenesis. A. Adventitious shoots induced from a internodal segment on MS medium supplemented with $0.5 \mathrm{mgl}^{-1}$ BAP 15 days after inoculation (bar $=$ $2 \mathrm{~cm})$. B. A part of shoot cluster regenerated from a internodal segment on same variant of medium 30 days after culture $(\mathrm{bar}=2 \mathrm{~cm})$. C. Rooted shoot produced on half steangh MS medium supplemented with $0.05 \mathrm{mgl}^{-1}$ NAA 21 days after culture (bar $=2 \mathrm{~cm}$ ). D. Acclimatized 2-month-old plantlet with flower growing in the flowering season onto a pot containing compost soil in the ex vitro conditions $(\mathrm{bar}=4 \mathrm{~cm})$.

The internodal segments were subcultured repeatedly on MS medium supplemented with $0.5 \mathrm{mgl}^{-1} \mathrm{BAP}$ to achieve continuous production of healthy shoots. The number of shoots per explant rapidly increased from the $1^{\text {st }}$ subculture up to the $4^{\text {th }}$ subculture and more than 150 shoots were produced per explant at the $4^{\text {th }}$ subculture. Similar shoot number was observed until the $6^{\text {th }}$ subculture and then drastically decreased in the subsequent subcultures. No remarkable differences were observed in the length of shoots throughout subcultures (Fig. 3). The stability of the shoot regeneration efficiency in the subculture depends on the plant species. The shoot number per leaf segment-derived calluses was reached highest level at the $5^{\text {th }}$ subculture and stable up to the $7^{\text {th }}$ subculture in Elaeocarpus robustus (Rahman et al., 2009) and the similar investigation also carried out in Lagerstroemia speciosa (Rahman et al., 2010) where stability of highest shoot production was continued from 6 th to $8^{\text {th }}$ subculture. Lethal browning in the tissue could be occurred by long-term subculture onto shoot-induction medium, which could lead to reduction of shoot regeneration efficiency in the subcultures. Horgan (1987) observed that the presence of cytokinin in the medium seems to enhance tissue browning for long-term culture, which inhibit shoot regeneration efficiency.

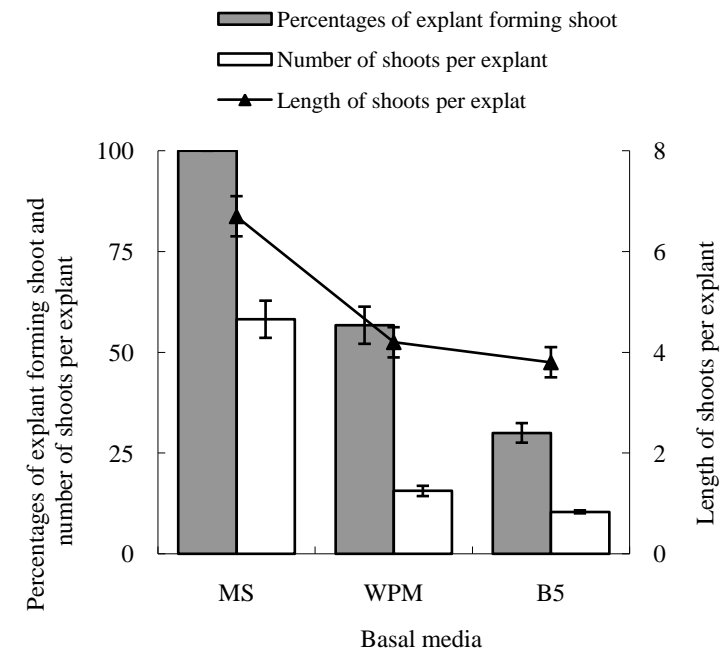

Fig. 2. Effect of three basic media on shoots regeneration from internodal segment 30 days after culture. All basal media were fortified with $0.5 \mathrm{mgl}^{-1} \mathrm{BAP}$.

\section{Rooting of shoot and acclimatization of plantlet}

The MS medium containing $0.5 \mathrm{mgl}^{-1}$ BAP-induced shoots were cultured on rooting-medium. Root initiation occurred within 7 days; an efficient root system was observed 21 days after culture (Fig. 1c). The addition of 0.01 and $0.05 \mathrm{mg} / \mathrm{l} \mathrm{NAA}$ to the half strength MS medium was the most effective for root induction without basal callusing. On both variants of rooting medium, $100 \%$ shoot induced root but significant differences $(p \leq 0.05)$ were observed in the root number (Table 3). The root formation was observed at the cut base of $65 \%$ shoots with a few number (2.7) on auxinfree medium; in contrast, the best rooting of $S$. surattense was observed on PGR-free MS medium (Pawar et al., 2002). The differences in the root 
induction efficiency were not observed within replications, in which variation in the root induction efficiency did not affected by genotypic variation of donor plants. The induction of root was also obtained on medium containing $0.05 \mathrm{mg} / \mathrm{l}$ of IBA and IAA but they showed stunt growth and thin, while callus was formed at shoot base. The other concentrations of IBA and IAA could not induce any root without forming callus. The best rooting responses from shoots on medium containing NAA were reported in many plant species (e.g., Teo et al., 1997). The callus induction at the cut base was a vital reason for inhibition of root induction, reported in Drymaria cordata (Ghimire et al., 2010).

About $90 \%$ of the plantlets survived onto compost soil 2 months after transfer and seasonal flowering observed in the ex vitro conditions. The detectable variation in the in vitro grown potted plants was not found when compared with the donor plants (Fig. 1d). The established shoot regeneration technique in the present study has a potential impact for clonal propagation of elite genotypes and improvement characteristics by molecular breeding technique of $S$. surattense for plantation and utilization in the drug industries. $\neg$ Number of shoots per explant

$\multimap$ Length of shoots per explant

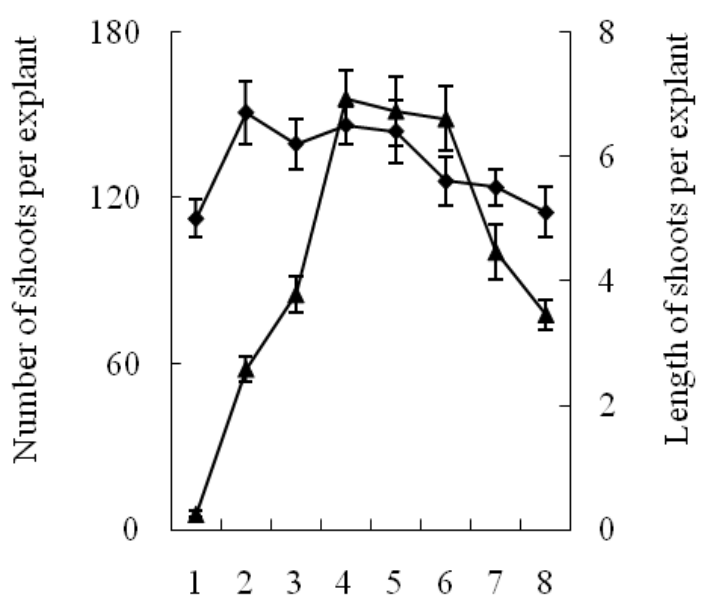

Subcultures

Fig. 3. The shoot regeneration ability per internodal segment throughout eight subcultures. The explants were repeated subculturing on MS medium supplemented with $0.5 \mathrm{mgl}^{-1} \mathrm{BAP}$.

\section{REFERENCES}

Benson, E.E., 2000. Special symposium: in vitro plant recalcitrance. Do free radicals have a role in plant tissue culture recalcitrance? In Vitro Cell Dev. Biol. Plant. 36, 163-170.

Bhat, M.A., Mujib, A., Junaid, A., Mahmooduzzafar, 2010. In vitro regeneration of Solanum nigrum with enhanced solasodine production. Biol. Planta. 54, 757-760.

Cham, B.E., 2007. Solasodine rhamnosyl glycosides specifically bind cancer cell receptors and induce apoptosis and necrosis. Treatment for skin cancer and hope for internal cancers. Res. J. Biol. Sci. 2, 503-514.

Cousson, A., Tran, Thanh Van K., 1993. Influence of ionic composition of the culture medium on de novo flower formation in tobacco thin cell layers. Can. J. Bot. 71, 506-511.

Ghimire, B.K., Seong, E.S., Goh, E.J., Kim, N.Y., Kang, W.H., Kim, E.H., Yu, C.Y., Chung, I.M., 2010. Highfrequency direct shoot regeneration from Drymaria cordata Willd. leaves. Plant Cell Tiss. Organ Cult. 100, 209-217.

Horgan, K., 1987. Pinus radiate. In J. M. Bonga \& D. J. Durzan (eds), Cell and Tissue Culture in Forestry (pp. 128-145. vol 3.), Martinus Nihoff, Dordrecht.
Mujib, A., 2005. In vitro regeneration of sandal (Santalum album L.) from leaves. Turk. J. Bot. 29, 63-67.

Pawar, P.K., Pawar, C.S., Narkhede, B.A., Teli, N.P., Bhalsing, S.R., Maheshwari, V.L., 2002. A technique for rapid micropropagation of Solanum surattense Burm. f. Indian J. Biotech. 1, 201-204.

Pinto, G., Silva, S., Park, Y-S., Neves, L., Araujo, C., Santos, C., 2008. Factors influencing somatic embryogenesis induction in Eucalyptus globulus Labill.: basal medium and anti-browning agents. Plant Cell Tiss. Organ Cult. $95,79-88$.

Prasad, R.N., Sharma, M., Sharma, A.K., Chaturvedi, H.C., 1998. Androgenic stable somaclonal variant of Solanum surattense Burm.f., Indian J. Exp. Biol. 36, 1007-1012.

Rahman, M.M., Amin, M.N., Ishiguri, F., Yokota, S., Sultana, R.S., Takashima, Y., Iizuka, K., Yoshizawa, N., 2009. In vitro plantlet regeneration of "dwarf" Indian olive (Elaeocarpus robustus Roxb.): a fruit plant of Bangladesh. Plant Biotech. Rep. 3, 259-266.

Rahman, M.M., Amin, M.N., Rahman, M.B., Sultana, R.S., 2010. In vitro adventitious shoot organogenesis and plantlet regeneration from leaf-derived callus of Lagerstroemia speciosa ( L.) Pers. Propagation Ornamen. Plants. 10, 149-155. 
Rama Swamy, N., 2006. Biotechnological applications for improvement of Solanum surattense: a medicinal plant. Daya Publishing House, Warangal, India, 145 pp.

Rama Swamy, N., Ugandhar, T., Praveen, M., Lakshman, A., Rambabu, M., Venkataiah, P., 2004. In vitro propagation of medicinally important Solanum surattense, Phytomorph. 54, 281-289.

Rama Swamy, N., Ugandhar, T., Praveen, M., Rambabu, M., Upender, M., 2005b. Induction of streptomycin-resistant plantlets in Solanum surattense through in vitro mutagenesis Plant Cell Tiss. Organ Cult. 80, 201-207.

Rama Swamy, N., Ugandhar, T., Praveen, M., Venkataiah, P., Rambabu, M., Upender, M., Subhash K., 2005a. Somatic embryogenesis and plantlet regeneration from cotyledon and leaf explants of Solanum surattense. Indian J. Biotech. 4, 414-418.
Ramage, C.M., Williams, R.R., 2002. Mineral nutrition and plant morphogenesis. In Vitro Cell. Dev. Biol.Plant. 38, 116-124.

Rastogi, S., Dwivedi, U.N., 2006. Down-regulation of lignin biosynthesis in transgenic Leucaena leucocephala harboring o-methyltransferase gene. Biotechnol. Prog. 22, 609-616.

Tazawa, M., Reinert, J., 1969. Extracellular and intracellular chemical environments in relation to embryogenesis in vitro. Protoplasma. 68, 157-173.

Teo, W., Lakshmanan, P., Kumar, P., Goh, C-J., Swarup, S., 1997. Direct shoot formation and plant regeneration from cotyledon explants of rapid-cycling Brassica rapa. In Vitro Cell. Dev. Biol. Plant. 33, 288-292. 